\section{Development of Transport}

Sir Arexander Gibb devoted the main part of his presidential address to the Institution of Civil Engineers, delivered on November 3, to an account of some of the works of civilization for which engineers and engineering-in the widest sense-have been responsible. Dealing first with means of transport, he said that the age of roads has now returned. More than 1,000,000 miles of modern roads serve the Empire ; that this is still only the beginning is clear from the fact that in Kenya, out of 10,500 miles, only 723 have a metalled surface, the remainder being earth-roads impassable after heavy rain, and in the 370,000 square miles of Nigeria, more than half the 15,000 miles of road are fair-weather roads only. What is required is road planning on really Imperial lines, and the social and political effects would be tremendous. Railway construction in the Empire dated from the middle of the last century. In 1850 Canada had 66 miles of railway; she has now 43,000 miles. With the railways came the steamship era. While the commercial application of the aeroplane has not yet been doveloped very far, Sir Alexander mentioned that it was almost wholly by air transport that the New Guinea goldfields and various gold and eopper mines in northern Canada were opened up. In New Guinea, all the machinery and parts for two large dredgers and a hydro-electric plant of several thousand horse-power were carried wholly by aeroplane over a range of mountains $5,000 \mathrm{ft}$. high into the interior, and then assembled and put to work within a year.

\section{Engineers and Empire Development}

ENGINEERING, or turning to practical account the discoveries of science, Sir Alexander said, is the foundation of civilization. In his opinion, the opportunities of the future are vastly greater than any that the past offered, but he regards with some anxiety the years-to come. The machine sometimes seems to be taking control; inventions and developments succeed one another with bewildering speed, and there seems to be no limit to the possible results of uncontrolled and misapplied ingenuity. Engineering provides directly or indirectly the livelihood of about a seventh of the working population of Great Britain. To-day is an age of ever-increasing specialization, and it has inevitably resulted in engineering being split up into many different categories and groups. If the great problems of the future are to be adequately dealt with, an attempt should be made to co-ordinate and unite engineering activities in the broadest sense, The Institution of Civil Engineers is taking steps in this matter, and useful work has already been done in the wider question of co-operation with engineering institutions. Sir Alexander thinks that one broad policy should inspire and guide all classes of engineers ; there might then arise a body of engineering opinion so weighty, so sane, that it would prevent waste of energy and misplaced enterprise, and would inevitably command attention in the politics, administration and life of Great Britain and the Empire.

\section{Kincardine-on-Forth Bridge}

THE Kincardine-on-Forth Bridge which was opened to traffic on October 29 will be a great boon to motorists. Hitherto, traffic from Edinburgh to the north bank of the Forth had to cross either by the ferry at Queensferry or by the bridge at Stirling twenty-five miles to the west. The new road bridge is situated nine miles down stream from Stirling. The bridge is half a mile long, and its most interesting feature is the electrically operated swing span in the centre. This span, which rotates on a central pier, weighs 1,600 tons and has a length of $364 \mathrm{ft}$.- - probably the longest span of this type in the world. It provides two clear openings for shipping each $150 \mathrm{ft}$. wide. A roadway $30 \mathrm{ft}$. wide with two 5 -ft. footpaths goes over the bridge. The whole of the equipment is controlled from a cabin at the top of the span. The saving in mileage between Edinburgh and Dunferm. line by this bridge amounts to 20 miles. The cost of the bridge was $£ 350,000$; the consulting engineers are Sir Alexander Gibb and Partners.

Tre turning gear of the swing span of the new bridge is driven by two fifty horse-power motors, but only about a fifth of the full power is required. The main position indicator on the control desk gives an alignment with an accuracy not greater than a few inches. But an inaccuracy so large as this would prevent the wedges and bolts being shot. To overcome this difficulty, two independent aligning systems have been installed, one employing photoelectric cells and the other using a target sight lighting principle. As the end of the swing span approaches its aligning position, the first photo-cell passes across a beam of light. This causes one of three lamps on the control desk to light up and a bell to give one stroke. As the span continues to move, the photo-cell crosses other light beams giving a total of three distinct light and sound warning signals. When another photo-cell arrives opposite a narrow slot, the middle lamp on the control desk indicates correct alignment.

\section{The Heat Engine in the Seventeenth Century}

Ir is generally known that Newcomen was the first to produce a practical cylinder and piston steam engine, but there is a singular lack of evidence to show where he obtained his ideas. Various statements, some of them quite unsubstantiated, about the matter have been made, but little is known with certainty. No one has examined the subject with greater care than Mr. Rhys Jenkins, who at a meeting of the Newcomen Society on October 21 read a paper entitled "The Heat Engine Idea in the Seventeenth Century". In this he impartially reviewed some of his own previous views and endeavoured to trace how the idea of applying heat for motive power might have been handed on from one projector to another in the course of the period 1612-1712. In turn, he referred to the writings and experiments of de Caus, David Ramsay, the Marquis of Worcester, Morland, Papin and Savery. To Papin certainly appears to belong the honour of producing a vacuum 